\title{
La distinction inachevée
}

\author{
Danielle Dussault
}

\section{Incomplete Distinction}

What they reproached her with was not having the virus, or at least of no longer having the virus which had existed for centuries and which everyone caught. The virus is caught through the feet and climbs through the veins to the heart and then the brain. It manifests itself as funny noises in the voice, then it attacks the voice and abolishes laughter leaving a gentle, smiling person. Except this one person who laughed loudly like a mountain. Until one day she came to me asking for an explanation about the virus. As I was talking to what seemed to be an audience, suddenly her face changed and she was no longer laughing, at least it no longer rang out, though something renained, like the ground after the war. A nice smiling person who, I assure you, wouldn't harm a fly.

En somme, ce qu'on lui reprochait, c'était de ne pas avoir le virus. Peut-être en avait-elle souffert autrefois, mais plus maintenant.

Le virus, qui ne le sait pas, se propageait dupuis des millénaires. Il avait fait son apparition dans les tribus anciennes, chez les sauvages.

Le virus s'attrapait par les pieds. On avait découvert cela au terme de fines et laborieuses recherches sur les sauvages. Il fallait bien trouver des coupables. Dès lors, cela devenait facile de faire des liens, tous les sauvages marchent pieds nus, alors forcément un malaise s'installe. N'est-ce pas?

L'indésirable s'infiltrait d'abord sous la peau des pieds, puis montait, montait par le chemin des veines, jusqu'au coeur, il y séjournait un temps, parfois toute une vie, puis il se hissait jusqu'au cerveau et là, il faisait son ravage. 
On a rapporté des cas fascinants chez les sauvages, certains se mettaient à danser la nuit, produisaient toutes sortes de bruits insolites avec leur voix, enfin avec ce qui leur restait de voix, car un des effets $\mathrm{du}$ virus se manifestait d'abord par une attaque de voix, puis par l'abolition du rire, ensuite plus rien, une personne gentille, souriante qui ne fait pas de mal à une mouche, plus jamais.

Le virus s'était modifié au fil des années, heureusement. Il ne s'attrapait plus par les pieds, mais par le cerveau. Heureusement. Il entrait tout doucement dans la région nerveuse, $s^{\prime}$ infiltrait mine de rien, car il avait acquis le talent si pratique de passer inaperçu. Il se reposait avant de descendre jusqu'au coeur pour débrancher les fils encombrants qui l'empêchaient d'agir à sa guise. Puis de nouveau il montait à la tête pour établir son royaume.

De nos jours, il n'enlevait pas toute la sensibilité, non il laissait des traces, une sorte d'imitation du rire, une espèce de reproduction au niveau de la voix, cela avait même un son étrange, synthétique. Le virus faisait désormais partie de la vie. Il épousait tous les humains sans distinction.

Sauf que.... Comment se faisait-il qu'elle n'en semblait pas atteinte? Tout le monde avait le virus, pourquoi pas elle? C'était comme porter un foulard rouge autour de la tête, alors que tout le monde en portait des blancs. Cela faisait déplacé.

Lorsqu'elle riait, vraiment trop fort, un rire bruyant, quelque chose qui ressemblait à une montagne que l'on déplace, c'était évident alors, on devinait que le virus modifiait pas encore son comportement.

Elle s'en excusait du mieux qu'elle pouvait, se livrait, pourquoi pas, à des séances de mortifications qui, lorsqu'elles étaient bien menées, produisaient un effet de tranquillité tout à fait rédemptoire.

Puis ça revenait. Le rire, la voix qui n'a pas de milieu, une variété d'imperfections accumulées, les marques d'un corps qui déraisonne. Il fallait sévir avant que ces manifestations ne prennent des proportions difficiles à contrôler. Personne ne le lui disait, mais certains 
regards parfois, des ordonances polies, une réflexion savante sur l'art de vivre avec un virus.

Elle écoutait sérieusement ce qu'on lui disait, mais peine perdue. Toujours un mot la faisait rire pour rien, même lorsqu' elle s'en défendait de sa meilleure volonté, cela persistait.

Aussi lorsqu'elle a frappé chez moi un jour, je n'ai pas été étonnée. Tout de suite, j'ai vu à quoi elle voulait en venir. J'ai fait semblant de rien, elle allait sûrement me le demander, il fallait la laisser parler jusqu'à ce qu'elle m'implore. Mais enfin, un malaise, ça ne s'attrape pas comme on veut!

Enfin lorsqu'elle m'a suppliée de lui révéler le secret du virus, j’ai pu le lui expliquer fort savamment, avec des termes choisis, une diplomatie agile et sonore, ma voix jamais ne m'avait paru aussi parfaitement synthétique. Et c'est étrange, parce que tout à coup, pendant que je discutais devant ce qui me semblait être un auditoire, même si nous n'étions que deux, tout à coup, j'ai vu son regard changer, elle ne riait plus, en tout cas le timbre s'était modifié, il en restait quelque chose bien sûr, comme il subsiste encore un sol après la guerre, mais cela résonnait maintenant d'une façon linéaire, absente. Et puis plus rien, une personne gentille souriante, tout à fait, qui, je vous assure, ne ferait pas de mal à une mouche. 